Research and Development Journal Of Education

Vol. 5 No. 2 April 2019

p-ISSN 2406-9744

e-ISSN 2657-1056

\title{
PENGARUH MINAT DAN MOTIVASI BELAJAR TERHADAP PRESTASI BELAJAR ILMU PENGETAHUAN SOSIAL (Survei pada siswa kelas VIII MTs Swasta di Jakarta Timur)
}

\author{
Ibnu Fiqhan Muslim \\ Pendidikan Ekonomi, FIPPS, Universitas Indraprasta PGRI Jakarta \\ enchan.chandra@gmail.com
}

\begin{abstract}
The purpose of this research is knowing how far effect of learning interest and learning motivation toward learning achievement, learning interest toward learning achievement, learning motivation toward learning achievement on social sciences subject. The Research method is using survey with correlation analysis and regression. Data about motivation study variabel and study motivation obtain by questionnairre which is prepared by researcher, that is measuring related two things above. Meanwhile data about studi achievement social subject obtain by direct test by researcher towards respondent. The results of the analysis state: (1) There is a significant influence together of interest and motivation to study on students' social studies learning achievement, this is evidenced by the Sig 0,000<0,05 and F count $=66,487$. While the magnitude of the contribution of interest and motivation to learn together on social studies learning achievement is shown by the coefficient of determination that is equal to $70 \%$ while the remaining $30 \%$ is due to other factors not examined. (2) There is a significant effect of learning interest on students' social studies learning outcomes. This is evidenced by the Sig $0,000<0,05$ and $t$ count $=4,724$. (3) There is a significant effect of students 'learning motivation on students' social studies learning outcomes. This is proven by the Sig 0,001<0,05 and t count $=3,457$.
\end{abstract}

Keywords: learning interest, learning motivation, learning achievement

\section{PENDAHULUAN}

Pendidikan merupakan suatu hal yang sangat penting dan tidak dapat dipisahkan dari kehidupan seseorang, baik dalam keluarga, masyarakat dan bangsa. Dalam proses pendidikan titik beratnya terletak pada siswa yaitu terjadi interaksi proses belajar dengan pengalaman yang dialami. Belajar mengakibatkan terjadinya perubahan pada diri orang yang belajar. Perubahanya meliputi aspek kognitif, afektif, dan psikomotorik.

Pendidikan IPS (Ilmu Pendidikan Sosial) sebagai salah satu bagian dari program pendidikan, dihadapkan pula kepada tantangan untuk dapat meningkatkan mutu pendidikan di Indonesia, sehingga menghasilkan manusia Indonesia yang mampu berbuat dan berkiprah dalam kehidupan manusia modern. Dengan kata lain dalam ilmu sosial tidak ada yang tetap karena yang tetap adalah perubahan. Barangkali sangat tepat untuk menggambarkan masyarakat dunia yang saat ini sedang mengalami perubahan yang begitu cepat. 
Research and Development Journal Of Education

Vol. 5 No. 2 April 2019

p-ISSN 2406-9744

e-ISSN 2657-1056

Pengetahuan sosial adalah bahan kajian yang terpadu yang merupakan penyederhanaan, adaptasi, seleksi dan modifikasi dari konsep-konsep dan ketrampilan- ketrampilan disiplin ilmu sejarah, geografi, sosiologi, antropologi dan ekonomi yang diorganisasikan secara ilmiah dan psikologis untuk tujuan pembelajaran. Di kalangan siswa MTS mata pelajaran Ilmu Pengetahuan Sosial (IPS) dianggap sebagai pelajaran yang terbatas pada hafalan saja, sehingga timbul kecenderungan mereka beranggapan bahwa IPS merupakan bidang studi yang menjemukan, kurang bergengsi dan kurang menantang minat dan motivasi belajar siswa. Hasil belajar siswa MTs pada matapelajaran IPS pun juga relatif rendah.

Ilmu IPS intregasi dari barbagai cabang ilmu sosial seperti: Sosiologi, Sejarah, Geografi, Ekonomi, Politik, Antropologi, Hukum dan Budaya. Ini artinya IPS bukan disiplin ilmu mandiri. Guru, dalam pembelajaran IPS dewasa ini, banyak menekankan pada siswa dalam menghafal materi bukan menjadikan materi menjadi mudah untuk dihafal oleh siswa, minimnya praktikum karena fasilitas yang kurang atau karena guru kurang sehingga timbul kejenuhan anak dalam belajar IPS.

Minat siswa MTs pada pelajaran IPS relatif rendah dilihat dari hasil evaluasi belajar peserta didik, sehingga hasil belajar IPS belum sepenuhnya menunjukkan hasil yang signifikan. Agar materi IPS yang akan diajarkan mudah diterima oleh peserta didik, maka diperlukan proses pembelajaran yang dapat membuat proses tersebut menjadi menyenangkan. Kesan bahwa pelajaran IPS hanya hafalan hampa tanpa makna harus segera dihilangkan.

Selain minat, keberhasilan siswa dalam belajar juga dipengaruhi oleh faktor motivasi belajar. Motivasi belajar juga berperan penting dalam keberhasilan belajar siswa, karena motivasi merupakan dorongan yang timbul dari diri siswa secara sadar atau tidak sadar yang bisa muncul dari dalam diri sendiri atau dari luar dirinya, untuk melakukan tindakan dengan tujuan tertentu. Motivasi adalah usaha-usaha yang menyebabkan seseorang atau kelompok orang bergerak melakukan sesuatu karena ingin mencapai tujuan yang dikehendaki. Dalam kegiatan belajar, motivasi sangat diperlukan, sebab seseorang yang tidak mempunyai motivasi dalam belajar, tidak akan mungkin melakukan aktivitas belajar. Motivasi siswa MTs sangat rendah terutama pada pelajaran yang bersifat 
Research and Development Journal Of Education

Vol. 5 No. 2 April 2019

p-ISSN 2406-9744

e-ISSN 2657-1056

teori khususnya pada pelajaran IPS. Hal tersebut juga bisa dilihat dari hasil evaluasi belajar peserta didik serta keluhan dari pada guru yang mengajar.

Dari beberapa uraian diatas penulis tertarik untuk meneliti beberapa faktor yang mendukung atau mempengaruhi prestasi belajar siswa Ilmu Pengetahuan Sosial yakni minat belajar dan motivasi belajar siswa yang kemudian terangkai dengan tema pengaruh minat dan motivasi belajar siswa terhadap prestasi belajar Ilmu Pengetahuan Sosial khususnya untuk siswa MTs.

\section{TINJAUAN PUSTAKA}

Dalam suatu penelitian diperlukan dukungan hasil penelitian yang telah ada sebelumnya yang berkaitan dengan penelitian tersebut. Definisi minat adalah suatu rasa suka dan rasa ketertarikan pada suatu hal atau aktivitas, tanpa ada yang menyuruh dan cenderung untuk memberikan perhatian yang lebih besar terhadap hal atau aktivitas tersebut (Slameto, 2010:180). Menurut Hilfard dalam Slameto (2010: 57) menyatakan bahwa: "Interest is persisting tendency to pay attention to and enjoy same activities and or content." ("Minat adalah kecenderungan yang tetap untuk memperhatikan dan mengenang beberapa kegiatan").

Menurut Djoko Restyo Putra (2011:21), minat yang kuat akan menimbulkan usaha yang gigih serius dan tidak mudah putus asa dalam menghadapi tantangan. Jika seseorang siswa memiliki rasa ingin belajar, ia akan cepat dapat mengerti dan mengingatnya. Fungsi minat bagi kehidupan anak, salah satunya yaitu minat sebagai pendorong tenaga yang kuat serta prestasi selalu dipengaruhi oleh jenis dan intensitas minatnya. Belajar dengan minat akan mendorong siswa belajar lebih baik daripada belajar tanpa minat. Namun demikian, minat tanpa adanya usaha yang baik maka belajar juga sulit untuk berhasil. (Oemar Hamalik, 2010:33).

Menurut Sanjaya, (2009) ada beberapa hal yang perlu dilakukan oleh seorang guru untuk meningkatkan motivasi belajar siswa, yaitu sebagai berikut:

a) Memperjelas tujuan yang ingin dicapai.

b) Membangkitkan motivasi siswa

c) Ciptakan suasana yang menyenangkan dalam belajar

d) Mengguanakan variasi metode penyajian yang menarik

e) Berilah pujian yang wajar setiap keberhasilan siswa 
Research and Development Journal Of Education

Vol. 5 No. 2 April 2019

p-ISSN 2406-9744

e-ISSN 2657-1056

f) Berikan penilaian

g) Berikan komentar terhadap hasil pekerjaan siswa

h) Ciptakan persaingan dan kerjasama

Definisi belajar menurut Hilgard dan Bower dalam Purwanto (2010: 84) mengatakan bahwa: "Belajar berhubungan dengan perubahan tingkah laku seseorang terhadap sesuatu situasi tertentu yang disebabkan oleh pengalamannya yang berulangulang dalam situasi itu, di mana perubahan tingkah laku itu tidak dapat dijelaskan atau dasar kecenderungan respon pembawaan, kematangan, atau keadaan-keadaan sesaat seseorang (misalnya kelelahan, pengaruh obat, dan sebagainya)."

Kemudian Gagne dalam Purwanto (2010: 84) yang mengemukakan bahwa: "Belajar terjadi apabila suatu situasi stimulus bersama dengan isi ingatan mempengaruhi siswa sedemikian rupa sehingga perbuatannya (performance-nya) berubah dari waktu sebelum ia mengalami situasi itu ke waktu sesudah ia mengalami situasi tadi." Masih dalam Purwanto (2010:84) Morgan menyatakan bahwa: "Belajar adalah setiap perubahan yang relatif menetap dalam tingkah laku yang terjadi sebagai suatu hasil dari latihan atau pengalamannya."

Menurut Syaodih (2009: 124) prestasi belajar merupakan segala perilaku yang dimiliki siswa sebagai akibat dari proses belajar yang ditempuhnya, meliputi semua akibat dari proses belajar yang berlangsung di sekolah atau di luar sekolah yang bersifat kognitif, afektif, maupun psikomotorik baik yang di sengaja ataupun yang tidak disengaja. Dimyati dan Mudjiono (2009:191) berpendapat bahwa evaluasi adalah proses sistematis untuk menentukan nilai sesuatu (tujuan, kegiatan, unjuk-kerja, proses, orang, objek, dan yang lain) berdasarkan kriteria tertentu melalui penilaian. Penilaian dilaksanakan dengan evaluasi pada PBM sehingga akan diketahui nilai dari prestasi belajar siswa. Syaodih (2009: 124) mengemukakan prestasi belajar merupakan segala perilaku yang dimiliki siswa sebagai akibat dari proses belajar yang ditempuhnya, meliputi semua akibat dari proses belajar yang berlangsung di sekolah atau di luar sekolah yang bersifat kognitif, afektif, maupun psikomotorik baik yang di sengaja ataupun yang tidak disengaja. 
Research and Development Journal Of Education

Vol. 5 No. 2 April 2019

p-ISSN 2406-9744

e-ISSN 2657-1056

\section{METODE}

Metode yang digunakan dalam penelitian ini adalah survei dengan teknik korelasional.

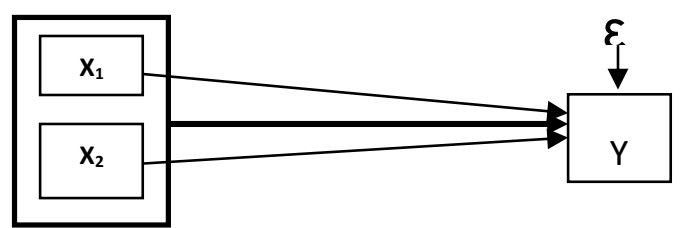

Gambar 3.1. : Konstelasi hubungan antar variabel penelitian

Keterangan :

Variabel Bebas (X1) : Minat belajar siswa

Variabel Bebas (X2) : Motivasi belajar siswa

Variabel Terikat (Y) : prestasi belajar siswa pada pelajaran IPS

$\varepsilon \quad$ : Variabel lain yang tidak diteliti

Populasi dalam penelitian ini adalah siswa kelas VIII MTs Swasta di wilayah Kota administrasi Jakarta Timur tahun pelajaran 2016/2017 yang berjumlah 537. Teknik pemilihan sampel dalam penelitian ini menggunakan teknik gabungan antara cluster, proporsional dan random. Teknik cluster digunakan dalam pengelompokan siswa menurut sekolah tempat belajar. Dalam menentukan jumlah anggota sampel digunakan teknik proporsional dari setiap sekolah yang ada di populasi terjangkau. Sedangkan untuk menentukan anggota sampel dari setiap sekolah yang ada digunakan teknik random. Jumlah anggota sampel dalam penelitian ini ditetapkan sebanyak 60 orang.

\section{Minat belajar}

Instrumen yang digunakan untuk mengumpulkan data minat belajar siswa berbentuk kuesioner dengan menggunakan rating scale.

\section{Motivasi belajar}

Kuesioner tentang motivasi belajar siswa ini yang disusun dalam 35 butir pertanyaan yang selanjutnya diuji validitas butir dan reliabilitas instrumen sehingga layak digunakan sebagai intrumen penelitian. Instrumen yang digunakan untuk mengumpulkan data tentang kepemimpinan kepala sekolah berbentuk kuesioner dengan menggunakan rating scale. 
Research and Development Journal Of Education

Vol. 5 No. 2 April 2019

p-ISSN 2406-9744

e-ISSN 2657-1056

\section{Prestasi belajar}

Prestasi belajar siswa pada pelajaran IPS adalah skor yang mencerminkan tingkat pencapaian kemampuan siswa pada pelajaran Ilmu Pengetahuan Sosial pada aspek pengetahuan, pemahaman dan aplikasi tentang materi sejarah yang diukur melalui tes/ulangan dengan soal berbentuk pilihan ganda.

\section{Teknik Analisis Data}

Untuk mempersingkat waktu, sekaligus pemanfaatan teknologi, maka perhitungan statistik deskriptif dalam penelitian ini akan diselesaikan menggunakan bantuan program komputer SPSS 20.0.

\section{a. Uji Normalitas}

Uji normalitas dapat dilakukan menggunakan analisis Kolmogorov Smirnov dalam SPSS 20.0. Distribusi data dikatakan normal jika nilai sig KS > 0,05. Perhitungan normalitas akan dilakukan menggunakan bantuan program komputer SPSS 20.0.

\section{b. Uji Linieritas}

Dalam prakteknya, akan digunakan bantuan program SPSS 20.0 untuk menghitung uji linieritas, yaitu dengan melihat besarnya nilai koefisien sig pada Deviation from Liniearity.

Kriteria pengujian linieritasnya adalah sebagai berikut:

Jika sig $>0,05$ maka garis regresi tersebut linier dan, Jika sig $\leq 0,05$ maka garis regresi tersebut tidak linier

\section{E. Hipotesis Statistik}

Hipotesis statistik dalam penelitian ini adalah sebagai berikut :

1. Hipotesis 1

$\mathrm{H}_{0} \quad: \quad \beta_{1}=\beta_{2}=0 \quad \rightarrow \quad$ tidak terdapat pengaruh minat belajar dan motivasi belajar secara bersama-sama terhadap prestasi belajar pada pelajaran IPS

$\mathrm{H}_{1} \quad: \quad \beta_{1} \neq 0$ atau $\beta_{2} \neq 0 \rightarrow$ terdapat pengaruh minat belajar dan motivasi belajar bersama-sama terhadap prestasi belajar pada pelajaran IPS

2. Hipotesis 2

$\mathrm{H}_{0}: \beta_{1}=0 \quad \rightarrow$ tidak terdapat pengaruh minat belajar terhadap prestasi belajar pada pelajaran IPS

$\mathrm{H}_{1}: \beta_{1} \neq 0 \quad \rightarrow$ terdapat pengaruh minat belajar terhadap prestasi belajar pada pelajaran IPS 
Research and Development Journal Of Education

Vol. 5 No. 2 April 2019

p-ISSN 2406-9744

e-ISSN 2657-1056

3. Hipotesis 3

$\mathrm{H}_{0} \quad: \quad \beta_{2}=0 \quad \rightarrow$ tidak terdapat pengaruh motivasi belajar terhadap prestasi belajar pada pelajaran IPS

$\mathrm{H}_{1}: \beta_{2} \neq 0 \quad \rightarrow$ terdapat pengaruh motivasi belajar terhadap prestasi belajar pada pelajaran IPS

\section{HASIL DAN PEMBAHASAN}

Tabel 2. Deskripsi data hasil perhitungan variabel $X_{1}, X_{2}$, dan $Y$

\begin{tabular}{|c|c|c|c|c|c|c|}
\hline & $N$ & Minimum & Maximum & Mean & Median & Std. Deviation \\
\hline Minat_Belajar & 60 & 66 & 117 & 95,02 & 95,5 & 13,594 \\
Motivasi_Belajar & 60 & 84 & 140 & 113,03 & 113 & 11,219 \\
Prestasi_Belajar_IPS & 60 & 48 & 92 & 75,53 & 76 & 9,7171 \\
\hline Valid N (listwise) & 60 & & & & & \\
\hline
\end{tabular}

\section{Analisis Data Variabel Minat Belajar $\left(\mathbf{X}_{1}\right)$}

Skor minat belajar yang diperoleh dari para responden mempunyai rata-rata 95,02 dengan simpangan baku 13,59, median sebesar 95,5, skor rata-rata tiap pertanyaan adalah 3,959 atau 79,18\%. Hal ini menunjukkan bahwa rata-rata skor minat belajar responden termasuk sedang. Skor simpangan baku 13,59 atau sama dengan 14,31\% dari rata-rata, menunjukkan perbedaan jawaban antar responden termasuk sedang. Hal ini menunjukkan bahwa minat belajar dari responden cukup beragam.

Nilai rata-rata dan dan median hampir sama, yaitu 95,02 dan 95,5. Hal ini menunjukkan bahwa data skor minat belajar siswa pada penelitian ini cukup representatif. Sedangkan skor yang berada di atas rata-rata sama dengan banyaknya skor yang berada di bawah rata-rata. Hal ini menunjukkan bahwa responden yang mempunyai minat belajar yang tinggi sama banyak dengan yang rendah.

Histogram dari data tersebut bisa dilihat pada gambar 1.

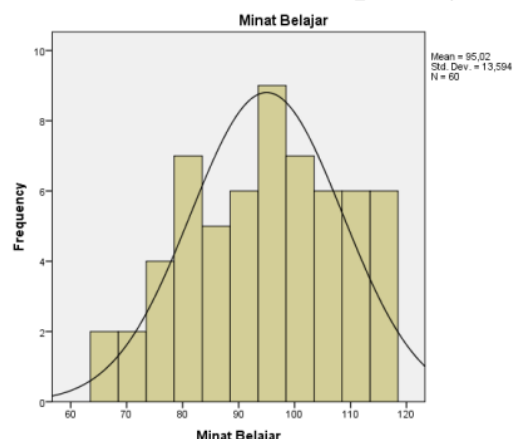

Gambar 1. Histogram Data Skor Minat Belajar 
Research and Development Journal Of Education

Vol. 5 No. 2 April 2019

p-ISSN 2406-9744

e-ISSN 2657-1056

Dari tabel distribusi, histrogram, dan poligon frekuensi dapat disimpulkan bahwa data skor skala minat belajar dalam penelitian ini memiliki sebaran yang cenderung normal.

\section{Analisis Data Motivasi Belajar $\left(\mathbf{X}_{2}\right)$}

Skor motivasi belajar yang diperoleh dari para responden mempunyai ratarata 113,03 dengan simpangan baku 11,22, median 113, skor rata-rata tiap pertanyaan adalah 3,7678 atau $75,36 \%$. Hal ini menunjukkan bahwa rata-rata motivasi belajar siswa termasuk sedang. Skor simpangan baku 11,22 atau sama dengan 9,93\% dari rata-rata, menunjukkan perbedaan jawaban antar responden termasuk sedang. Hal ini menunjukkan bahwa motivasi belajar yang dimiliki responen cukup banyak beragam.

Dari deskripsi tersebut juga dapat dilihat bahwa antara nilai rata-rata dan dan nilai tengah (median) hampir sama, yaitu 113,03 dan 113. Hal ini menunjukkan bahwa data skor motivasi belajar yang diperoleh pada penelitian ini cukup representatif. Sedangkan skor yang berada di atas rata-rata lebih sedikit dibanding yang berada di bawah rata-rata. Hal ini menunjukkan bahwa responden yang mempunyai motivasi belajar yang rendah lebih banyak dibanding yang mempunyai motivasi belajar yang tinggi, namun perbedaanya hanya sedikit.

Histogram dari data tersebut bisa dilihat pada gambar 2.

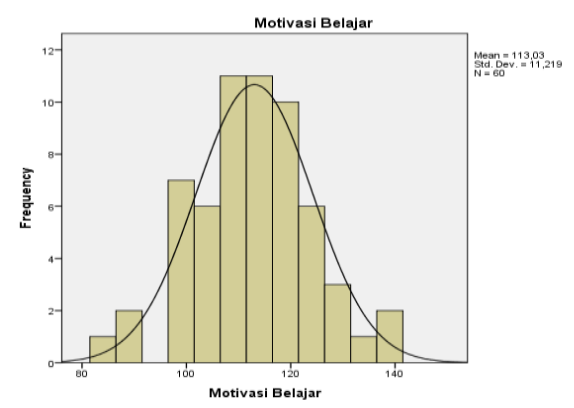

Gambar 2. Histogram Data Skor Motivasi Belajar

Dari tabel distribusi, histrogram, dan poligon frekuensi dapat disimpulkan bahwa data skor skala motivasi belajar siswa dalam penelitian ini memiliki sebaran yang cenderung normal.

\section{Analisa Data Prestasi Belajar IPS (Y)}

Data prestasi belajar IPS yang diperoleh dari responden mempunyai ratarata 75,53 dengan simpangan baku 9,72, median sebesar 76, skor minimum 48 
Research and Development Journal Of Education

Vol. 5 No. 2 April 2019

p-ISSN 2406-9744

e-ISSN 2657-1056

dan skor maksimum 92. Hal ini menunjukkan bahwa rata-rata prestasi belajar IPS yang dimilliki responden termasuk sedang. Jika mempertimbangkan ketuntasan belajar dimana siswa dikatakan tuntas belajar jika nilai yang diperoleh di atas Kriteria Ketuntasan Minimal (KKM) yang ditetapkan oleh sekolah. Pada penelitian ini KKM mata pelajaran IPS kelas VIII di sekolah tempat penelitian adalah 72, maka banyaknya responden yag tuntas sebanyak 45 orang atau $75 \%$. Jadi jika dilihat dari ketuntasan belajar, maka prestasi belajar IPS yang dimilliki responden juga sedang-sedang saja. Skor simpangan baku 9,72 atau sama dengan $12,86 \%$ dari rata-rata, menunjukkan perbedaan jawaban antar responden termasuk sedang. Hal ini menunjukkan bahwa prestasi belajar IPS yang dimilliki responden cukup beragam.

Dari deskripsi tersebut juga dapat dilihat bahwa antara nilai rata-rata dan dan nilai tengah (median) hampir sama, yaitu 75,53 dan 76. Hal ini menunjukkan bahwa data skor prestasi belajar siswa pada pelajaran IPS pada penelitian ini cukup representatif. Sedangkan skor yang berada di atas rata-rata lebih banyak dibanding yang berada di bawah rata-rata. Hal ini menunjukkan bahwa prestasi belajar responden pada pelajaran IPS yang berada di atas rata-rata lebih banyak dibanding yang dibawah rata-rata.

Histogram dari data tersebut bisa dilihat pada gambar 3.

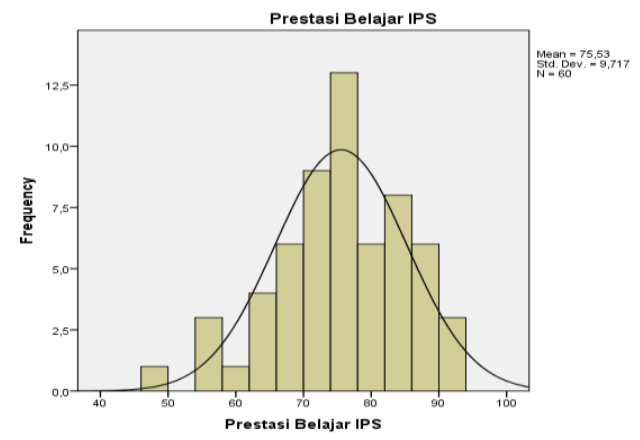

Gambar 3. Histogram Data Skor Prestasi Belajar Siswa pada Pelajaran IPS (Y)

Dari tabel distribusi, histrogram, dan poligon frekuensi dapat disimpulkan bahwa data skor skala prestasi belajar siswa pada pelajaran IPS dalam penelitian ini memiliki sebaran yang cenderung normal. 


\section{B. Pengujian Hipotesis}

\section{Pengaruh Minat $\left(\mathbf{X}_{1}\right)$ dan Motivasi Belajar $\left(\mathbf{X}_{2}\right)$ Secara Bersama-sama Terhadap Prestasi Belajar IPS (Y)}

Hipotesis statistik yang akan dibuktikan adalah :

$$
\begin{aligned}
& \mathrm{H}_{0}: \beta_{\mathrm{y} .1}=\beta_{\mathrm{y} 2}=0 \\
& \mathrm{H}_{1}: \beta_{\mathrm{y} .1} \neq 0 \text { dan } \beta_{\mathrm{y} 2} \neq 0 ;
\end{aligned}
$$

artinya :

$\mathrm{H}_{0}$ : tidak terdapat pengaruh minat belajar $\left(\mathrm{X}_{1}\right)$ dan motivasi belajar siswa $\left(\mathrm{X}_{2}\right)$ secara bersama-sama terhadap prestasi belajar IPS (Y)

$\mathrm{H}_{1}$ : terdapat pengaruh minat belajar $\left(\mathrm{X}_{1}\right)$ dan motivasi belajar siswa $\left(\mathrm{X}_{2}\right)$ secara bersama-sama terhadap prestasi belajar siswa IPS (Y)

Untuk membuktikan hipotesis tersebut, digunakan hasil perhitungan yang dilakukan dengan bantuan komputer melalui program aplikasi SPSS 20.0. Hasil perhitungan dan pembahsanannya adalah sebagai berikut :

Diperoleh persamaan garis regresi yang merepresentasikan pengaruh variabel $X_{1}$ dan $X_{2}$ terdahap variabel $Y$, yaitu $\widehat{\mathbf{Y}}=3,527+0,369 X_{1}+0,327 X_{2}$. Koefisien korelasi ganda pengaruh variabel bebas minat belajar $\left(\mathrm{X}_{1}\right)$ dan motivasi belajar $\left(\mathrm{X}_{2}\right)$ secara bersama-sama terhadap prestasi belajar IPS (Y) adalah sebesar 0,837. Dari perhitungan diperoleh bahwa koefisien korelasi tersebut signifikan, dengan kata lain bahwa terdapat pengaruh yang signifikan variabel bebas minat belajar $\left(\mathrm{X}_{1}\right)$ dan motivasi belajar $\left(\mathrm{X}_{2}\right)$ secara bersama-sama terhadap prestasi belajar IPS (Y). Sedangkan koefisien determinasinya adalah sebesar $70 \%$ menunjukkan bahwa besarnya kontribusi minat belajar dan motivasi belajar secara bersama-sama terhadap prestasi belajar IPS adalah sebesar 70\%, sisanya (30\%) karena pengaruh faktor lain.

Dari nilai Sig $0,000<0.05$ dan $\mathbf{F}_{\text {hitung }}=66,485$, maka $\mathrm{H}_{0}$ ditolak yang berarti bahwa koefisien regresi tersebut signifikan. Dengan kata lain bahwa terdapat pengaruh yang signifikan variabel bebas minat belajar $\left(\mathrm{X}_{1}\right)$ dan motivasi belajar $\left(\mathrm{X}_{2}\right)$ secara bersama-sama terhadap prestasi belajar IPS (Y). Dari hasil pengujian korelasi maupun pengujian regresi tersebut maka bisa disimpulkan bahwa terdapat pengaruh yang signifikan variabel bebas minat $\left(\mathrm{X}_{1}\right)$ dan motivasi belajar $\left(\mathrm{X}_{2}\right)$ secara bersama-sama terhadap variabel terikat $\mathrm{Y}$ (prestasi belajar IPS). 
Research and Development Journal Of Education

Vol. 5 No. 2 April 2019

p-ISSN 2406-9744

e-ISSN 2657-1056

\section{Pengaruh Minat belajar $\left(\mathrm{X}_{1}\right)$ terhadap Prestasi Belajar IPS (Y)}

Hipotesis statistik yang akan dibuktikan adalah :

$$
\begin{gathered}
\mathrm{H}_{0}: \beta_{\mathrm{y} 1}=0 \\
\mathrm{H}_{1}: \beta_{\mathrm{y} 1} \neq 0 \\
\text { artinya }:
\end{gathered}
$$

$\mathrm{H}_{0}$ : tidak terdapat pengaruh minat belajar $\left(\mathrm{X}_{1}\right)$ terhadap prestasi belajar IPS (Y)

$\mathrm{H}_{1} \quad$ : terdapat pengaruh minat belajar $\left(\mathrm{X}_{1}\right)$ terhadap prestasi belajar IPS (Y)

Dari nilai Sig $0,000<0.05$ dan $\mathbf{t}_{\text {hitung }}=4,724$, maka $\mathrm{H}_{0}$ ditolak yang berarti terdapat pengaruh yang signifikan variabel bebas $\mathrm{X}_{1}$ (minat belajar) terhadap variabel terikat Y (prestasi belajar IPS). Dari hasil pengujian korelasi, pengujian regresi maupun dengan melihat model garis tersebut maka bisa disimpulkan bahwa terdapat pengaruh yang signifikan variabel bebas $\mathrm{X}_{1}$ (minat belajar) terhadap variabel terikat Y (prestasi belajar IPS).

\section{Pengaruh Motivasi Belajar $\left(\mathbf{X}_{2}\right)$ terhadap Prestasi Belajar IPS (Y)}

Hipotesis statistik yang akan dibuktikan adalah :

$$
\begin{aligned}
\mathrm{H}_{0} & : \beta_{\mathrm{y} 2}=0 \\
\mathrm{H}_{1}: & \beta_{\mathrm{y} 2} \neq 0 \\
\text { artinya }: & \\
\mathrm{H}_{0} & : \text { tidak terdapat pengaruh motivasi belajar siswa }\left(\mathrm{X}_{2}\right) \text { terhadap prestasi } \\
& \text { belajar IPS (Y) } \\
\mathrm{H}_{1} & : \text { terdapat pengaruh motivasi belajar siswa }\left(\mathrm{X}_{2}\right) \text { terhadap prestasi } \\
& \text { belajar IPS }(\mathrm{Y})
\end{aligned}
$$

Dari nilai Sig $0,001<0.05$ dan $\mathbf{t}_{\text {hitung }}=3,457$, maka $\mathrm{H}_{0}$ ditolak yang berarti terdapat pengaruh yang signifikan variabel bebas $\mathrm{X}_{2}$ (motivasi belajar siswa) terhadap variabel terikat Y (prestasi belajar IPS). Dari hasil pengujian korelasi, pengujian regresi maupun dengan melihat model garis tersebut maka bisa disimpulkan bahwa terdapat pengaruh yang signifikan variabel bebas $\mathrm{X}_{2}$ (motivasi belajar) terhadap variabel terikat Y (prestasi belajar).

\section{Pembahasan}

Penelitian ini untuk mengetahui pengaruh minat belajar siswa dan motivasi belajar siswa terhadap prestasi belajar siswa pada pelajaran IPS. 
Research and Development Journal Of Education

Vol. 5 No. 2 April 2019

p-ISSN 2406-9744

e-ISSN 2657-1056

\section{Pengaruh Minat dan Motivasi Belajar Siswa Secara Bersama-sama terhadap Prestasi Belajar Siswa pada Pelajaran IPS}

Dari deskripsi data setelah dilakukan analisis korelasi diperoleh koefisien korelasi sebesar 0,837 dan koefisien determinasi sebesar 70\%, setelah dilakukan pengujian dengan program SPSS terbukti bahwa koefisien korelasi tersebut signifikan. Hal ini berarti bahwa terdapat pengaruh variabel bebas $\mathrm{X}_{1}$ (minat belajar) dan $\mathrm{X}_{2}$ (motivasi belajar) secara bersama-sama terhadap variabel terikat $\mathrm{Y}$ (prestasi belajar IPS).

Sedangkan dari analisis regresi diperoleh persamaan garis regresi $\widehat{\mathbf{Y}}=$ $3,527+0,369 \mathrm{X}_{1}+0,327 \mathrm{X}_{2}$. Nilai konstanta $=3,527$ menunjukkan bahwa dengan minat belajar dan motivasi belajar siswa paling rendah sulit bagi siswa tersebut untuk bisa meraih pretasi belajar yang baik, sedangkan nilai koefisien regresi sebesar 0,369 dan 0,327 menunjukkan bahwa terdapat pengaruh positif variabel bebas $\mathrm{X}_{1}$ (minat belajar) dan $\mathrm{X}_{2}$ (motivasi belajar) secara bersama-sama terhadap variabel terikat Y (prestasi belajar IPS). Angka koefisien regresi tersebut juga menunjukkan bahwa setiap ada kenaikan satu nilai minat belajar maka akan terdapat kenaikan prestasi belajar siswa sebesar 0,369, dan setiap ada kenaikan satu nilai motivasi belajar siswa maka akan terdapat kenaikan prestasi belajar siswa sebesar 0,327 .

Setelah dilakukan pengujian signifikansi koefisin regresi, diperoleh bahwa nilai Sig $=0.000$ dan $\mathbf{F}_{\text {hitung }}=66,465$, sedangkan $\mathbf{F}_{\text {tabel }}=3,15$ sehingga nilai Sig $0,000<0,05$ dan $\mathbf{F}_{\text {hitung }}>\mathbf{F}_{\text {tabel }}$ yang berarti regresi tersebut signifikan. Dari informasi kuantitatif dan teori yang telah di bahas sebelumnya maka dapat disimpulan bahwa terdapat pengaruh yang signifikan minat dan motivasi belajar siswa secara bersama-sama terhadap prestasi belajar siswa pada pelajaran IPS.

\section{Pengaruh Minat Belajar terhadap Prestasi Belajar Siswa pada Pelajaran IPS}

Dari pengujian hipotesis diperoleh bahwa nilai $\operatorname{Sig}=0.000$ dan $\mathrm{t}_{\text {hitung }}=$ 4,724, sedangkan $t_{\text {tabel }}=1,67$. Karena nilai Sig $0,000<0,05$ dan $t_{\text {hitung }}>t_{\text {tabel }}$ maka $\mathrm{H}_{0}$ ditolak yang berarti terdapat pengaruh yang signifikan variabel bebas $\mathrm{X}_{1}$ (minat belajar) terhadap variabel terikat Y (prestasi belajar IPS). Dari informasi kuantitatif dan teori yang telah dibahas sebelumnya maka peneliti berkesimpulan 
Research and Development Journal Of Education

Vol. 5 No. 2 April 2019

p-ISSN 2406-9744

e-ISSN 2657-1056

bahwa terdapat pengaruh positif dan signifikan minat belajar siswa pada terhadap prestasi belajar siswa pada pelajaran IPS.

\section{Pengaruh Motivasi Belajar Siswa terhadap Prestasi Belajar Siswa pada Pelajaran IPS}

Dari pengujian hipotesis diperoleh bahwa nilai Sig $=0.000$ dan $\mathrm{t}_{\text {hitung }}=$ 3,457 , sedangkan $t_{\text {tabel }}=1,67$. Karena nilai Sig 0,001 $<0,05$ dan $t_{\text {hitung }}>t_{\text {tabel }}$ maka $\mathrm{H}_{0}$ ditolak yang berarti terdapat pengaruh yang signifikan variabel bebas $\mathrm{X}_{2}$ (motivasi belajar) terhadap variabel Y (prestasi belajar IPS). Dari informasi kuantitatif dan teori yang telah dibahas sebelumnya maka peneliti berkesimpulan bahwa terdapat pengaruh positif dan signifikan motivasi belajar siswa terhadap prestasi belajar siswa pada pelajaran IPS.

\section{SIMPULAN}

\section{Simpulan}

Berdasarkan deskripsi data penelitian dan setelah dilakukan analisis maka dapat disimpulkan :

1. Terdapat pengaruh yang signifikan minat dan motivasi belajar secara bersamasama terhadap prestasi belajar IPS siswa MTs Swasta di Jakarta Timur. Hal ini dibuktikan dengan nilai Sig $0,000<0,05$ dan $\mathbf{F}_{\text {hitung }}=66,487$, yang berarti regresi tersebut signifikan. Sedangkan besarnya kontribusi minat dan motivasi belajar secara bersama-sama terhadap prestasi belajar IPS ditunjukkan oleh koefisien determinasi yaitu sebesar $70 \%$ sedangkan sisanya yaitu $30 \%$ disebabkan faktor-faktor yang lain yang tidak diteliti.

2. Terdapat pengaruh yang signifikan minat belajar terhadap prestasi belajar IPS siswa MTs Swasta di Jakarta Timur. Hal ini dibuktikan oleh hasil pengujian hipotesis yang diperoleh bahwa nilai Sig $0,000<0,05$ dan $\mathbf{t}_{\text {hitung }}=4,724$, yang berarti terdapat pengaruh yang signifikan.

3. Terdapat pengaruh yang signifikan motivasi belajar siswa terhadap prestasi belajar IPS siswa MTs Swasta di Jakarta Timur. Hal ini dibuktikan oleh hasil pengujian hipotesis yang diperoleh bahwa nilai Sig $0,001<0,05$ dan $\mathbf{t}_{\text {hitung }}=$ 3,457 , yang berarti terdapat pengaruh yang signifikan. 
Research and Development Journal Of Education

Vol. 5 No. 2 April 2019

p-ISSN 2406-9744

e-ISSN 2657-1056

\section{Saran}

Saran yang bisa penulis sampaikan pada kesempatan ini adalah sebagai berikut :

1. Hendaknya para guru, para pengelola lembaga pendidikan, serta para orang tua senantiasa memberi motivasi kepada siswanya/putranya agar mereka mempunyai semangat belajar, berprestasi dan berkompetisi untuk meraih kesuksesan yang setinggi-tingginya.

2. Hendaknya para pengelola sekolah memperhatikan semua faktor yang bisa menumbuhkan minat dan motivasi belajar siswa, misalnya dengan perbaikan dan penyediaan sarana belajar, menjaga lingkungan sekolah agar selalu kondusif dan nyaman untuk belajar, meningkatan kompetesi guru, dan lainlain. Semua hal tersebut semata-mata untuk menumbuhkan minat belajar siswa, karena jika semua kondisi tersebut terpenuhi, niscaya siswa akan mempunyai semangat minat dan motivasi belajar yang tinggi, dan tentunya akan berpengaruh pada peningkatan prestasi belajar siswa.

3. Hendaknya para guru dan para pengelola lembaga pendidikan bisa memadukan antara minat dan motivasi belajar dari para siswanya untuk meningkatkan prestasi belajar siswa, yang bermuara pada peningkatan kualitas pendidikan di sekolah.

\section{DAFTAR PUSTAKA}

Asmani, Jamal, M. (2009). Jurus-jurus Belajar Efektif Untuk SMP dan SMA. Yogyakarta: DIVA Press.

Dimyati, Mudjiyono. (2009). Belajar dan Pembelajaran. Jakarta: Rineka Cipta.

Muhibbin, Syah. (2010). Psikologi Pendidikan dengan Pendekatan Baru. Bandung: Remaja Rosdakarya.

Mutakin, Tatan Zaenal dan Maria Cleopatra. (2015). Suplemen Aplikasi Komputer Dalam Penyusunan Karya Ilmiah. Tangerang: Pustaka Mandiri.

Nana Syaodih Sukmadinata. (2009). Landasan Psikologi Proses Pendidikan. Bandung: PT Remaja Rosdakarya.

Oemar Hamalik. (2010). Proses Belajar Mengajar. Jakarta: Bumi Aksara.

Purwanto, M., Ngalim. (2010). Psikologi Pendidikan. Bandung: Remaja Rosdakarya.

Sanjaya, Wina. 2009. Strategi Pembelajaran Berorientasi Standar Proses Pendidikan. Jakarta : Kencana Prenada Media Group

Slameto. (2010). Belajar dan Faktor Faktor Yang Mempengaruhi. Jakarta: Rineka Cipta.

Suharsimi Arikunto. (2009). Manajemen Penelitian. Jakarta: Rineka Cipta. 
Research and Development Journal Of Education

Vol. 5 No. 2 April 2019

p-ISSN 2406-9744

e-ISSN 2657-1056

Suparman I.A. (2016). Aplikasi Komputer. Tangerang: Pustaka Mandiri.

Tim Penyusun. (2015). Panduan Penulisan Skripsi Tugas Akhir dan Tesis. Jakarta: Unindra-PGRI.

Unindra. (2010). Buku Panduan Penulisan Tesis Program Pascasarjana. Jakarta: Universitas Indraprasta PGRI 